\title{
The relative importance of above- versus belowground competition for tree growth during early succession of a tropical moist forest
}

\author{
Michiel van Breugel • Paulo van Breugel • \\ Patrick A. Jansen • Miguel Martínez-Ramos • \\ Frans Bongers
}

Received: 1 September 2011/ Accepted: 4 November 2011/Published online: 19 November 2011

(C) The Author(s) 2011. This article is published with open access at Springerlink.com

\begin{abstract}
Competition between neighboring plants plays a major role in the population dynamics of tree species in the early phases of humid tropical forest succession. We evaluated the relative importance of above- versus below-ground competition during the first years of old-field succession on soil with low fertility in Southern Mexico, using the premise that competition for light is size-asymmetric, unlike competition for nutrients. Plant growth is thus expected to be disproportionally impeded by larger neighbors. We
\end{abstract}

Electronic supplementary material The online version of this article (doi:10.1007/s11258-011-0003-3) contains supplementary material, which is available to authorized users.

M. van Breugel · P. A. Jansen

Center for Tropical Forest Science, Smithsonian Tropical

Research Institute, Av. Roosevelt 401, Balboa, Ancon,

Panama, Republic of Panama

M. van Breugel · P. A. Jansen · F. Bongers

Forest Ecology and Forest Management Group, Center for Ecosystem Studies, Wageningen University, P.O. Box 47, 6700 AA Wageningen, The Netherlands

M. van Breugel $(\bowtie) \cdot$ M. Martínez-Ramos

Centro de Investigaciones en Ecosistemas, UNAM, AP

27-3 Santa María de Guido, CP 58089 Morelia, MICH,

Mexico

e-mail: mvbreugel@gmail.com

P. van Breugel

Forest and Landscape Centre, Faculty of Life Sciences, Copenhagen University, Rolighedsvej 23, 1958

Frederiksberg C, Denmark studied how growth and survival of 3.5-5.5 m tall saplings of Cecropia peltata and Trichospermum mexicanum, two pioneer species that dominate the secondary forests in the study region, varied with the abundance and size of neighboring trees in 1-2 year old secondary vegetation. We found that local neighborhood basal area varied 10-fold (3 to $30 \mathrm{~cm}^{2} \mathrm{~m}^{-2}$ ) and explained most of the variation in diameter and height growth of the target saplings. Most growth variables were strongly affected by the neighbors bigger than the focal trees with no significant additive effect of the smaller neighbors, indicating asymmetric competition. Smaller neighbors did have a small but significant additive effect on the diameter growth of Cecropia saplings and stem slenderness of Trichospermum saplings. We conclude that competition for light was more important than belowground competition in this initial phase of moist tropical forest successional, despite the low soil fertility.

Keywords Forest succession - Asymmetric competition · Growth - Survival - Stem allometry · Light · Tropical moist forest $\cdot$ Mexico

\section{Introduction}

Secondary forests are becoming increasingly important throughout the tropics as old-growth forests are being cleared and cultivated land is being abandoned 
(Hansen and DeFries 2004). The conservation of biodiversity and ecosystem services provided by tropical forests are increasingly depending on the species composition and structure of these secondary forests (Chazdon et al. 2009; Dent and Wright 2009; Gardner et al. 2009). A major determinant of the species composition and structure of secondary forests is the course of early succession, when pioneer species with different demographic and functional characteristics compete to establish and set the template for further community assembly (Norden et al. 2011). With seed limitation and environmental filtering, competition for resources between neighboring plants is considered to be the main determinant of the species composition and structural development of tropical forests during early succession (Peet and Christensen 1980; Bazzaz 1990; Chazdon 2008). Competition plays a role as soon as resource neighboring plants start to overlap and intensifies with time as plants grow bigger and preempt an increasing proportion of the available resources (Bazzaz 1996; Keddy 2001; Grime 2002).

In the humid tropics, aboveground biomass can accumulate very rapidly during the first years of secondary forest succession (Swaine and Hall 1983; Uhl 1987; van Breugel et al. 2006; Fonseca et al. 2011), with the leaf area index (LAI) and understory light levels approaching old-growth values within just few years (Uhl 1987; Saldarriaga and Luxmoore 1991; Selaya et al. 2007; Kuijk et al. 2008). This finding has led to the commonly held assumption that competition for light plays a predominant role in the early phases of succession in humid tropical forest ecosystems.

However, where soil fertility is lower, nutrients may also be an important limiting factor (Wilson 1999), and successional models based solely on competition for light may not explain successional changes. For example, young secondary forest on soils with a long history of intensive pasture use in central Amazonia had much lower LAI, but not stand biomass compared to secondary forests on lighter-used soils (Feldpausch et al. 2005), suggesting a less prominent role of light. Moreover, it has been hypothesized that competition for nutrients dominates in the earliest phase of succession while competition for light becomes more important as stand biomass increases (Huston and Smith 1987; Belcher et al. 1995). To our knowledge, few studies have directly assessed the relative importance of competition for light relative to nutrients during tropical forest succession.

The relative importance of above versus belowground competition can be assessed by considering the asymmetry of competition (Schwinning and Weiner 1998). Competition for light is assumed to be predominantly asymmetric because larger plants shade smaller ones and capture a disproportionally larger share of the available light (Weiner 1990; Berntson and Wayne 2000; Potvin and Dutilleul 2009). Competition for soil water and nutrients, in contrast, is often taken to be symmetric, based on the premise that roots generate depletion zones around their surfaces and thus restrict resource availability for other roots relative to plant size (Noordwijk et al. 1996; Schwinning and Weiner 1998; Casper et al. 2003; but see Rajaniemi 2003). In temperate secondary forests, different degrees of asymmetry have been reported and it has been suggested that this reflects variation in the relative role of light competition among sites (Thomas and Weiner 1989; Peterson and Squiers 1995; Kikuzawa and Umeki 1996). The importance of light as a limiting factor may also be inferred from allocation patterns, as trees generally tend to allocate resources to height growth at the expense of diameter growth under low-light conditions, particularly in the case of early successional species (Kohyama and Hotta 1990; King 1996; Poorter 2001; Sterck 2005), making it a useful variable to assess the relative importance of competition for light in the early phases of succession.

In this study, we investigated the relative importance of above- and below-ground resources as factors limiting growth of pioneer species during forest succession on a nutrient-poor soil in southern Mexico. We used two tree pioneer species, Cecropia peltata L. and Trichospermum mexicanum (DC.) Baill. (henceforth referred to by genus name), which are the two most dominant species in the secondary forests in the study region and have similar characteristics (Table 1). Specifically, we test the hypothesis that sapling performance is disproportionally affected by the neighbors that are larger than the focal sapling. Strong asymmetry would indicate that aboveground competition (for light) is important, whereas symmetry would suggest that competition for belowground resources is more important. Our approach was to determine how individual growth over 1 year varied 
with the presence and the relative size of neighboring trees.

\section{Methodology}

Study site and data collection

Fieldwork was conducted in the Marqués de Comillas region in southern Chiapas, Mexico $\left(16^{\circ} 04^{\prime} \mathrm{N} ; 90^{\circ} 45^{\prime}\right.$ $\mathrm{W})$. The climate is characterized by an annual temperature of $23.8^{\circ} \mathrm{C}$, a mean annual rainfall of $2802 \mathrm{~mm}$ and a dry period (monthly precipitation $<$ monthly evaporation) from February to April. The study period was slightly wetter, with a total annual rainfall of $3017 \mathrm{~mm}$ and a dry period from March to April (CFE, División Hidrométrica Sureste, unpublished data). The original vegetation in the region is lowland moist tropical forests (Ibarra-Manríquez and Martínez-Ramos 2002) and consists currently of a mosaic of pastures, young (mostly $<10$ years) secondary forests, small-scale slash-andburn agriculture, and remnants of old-growth forests (de Jong et al. 2000; Zermeño Hernández 2008).

Data was collected in a young secondary forest on abandoned farmland that was cleared and burned from old-growth forest before cultivation, farmed for maize for one harvest period only and abandoned about 1.5 year before plot establishment. The forest was situated in an area with undulating hills (slopes $15-30^{\circ}$ ), the most common geomorphological unit in the region characterized by sandy Humic Acrisols with $\mathrm{pH}$ of $5.91( \pm 0.29 \mathrm{SE}), 0.26 \%( \pm 0.03 \mathrm{SE})$ total nitrogen, and $3.14 \mathrm{mg} / \mathrm{kg}( \pm 0.26 \mathrm{SE})$ phosphorous (I. Zermeño unpublished data). In September 2000, two plots of $10 \times 50 \mathrm{~m}$ were established at approximately
$200 \mathrm{~m}$ distance from each other in which all trees with a DBH (diameter at $1.3 \mathrm{~m}$ ) $\geq 1 \mathrm{~cm}$ were tagged, their $\mathrm{DBH}$ and height were measured and their position was established at the scale of $1 \times 1 \mathrm{~m}$ quadrats within a permanently indicated $2 \times 2 \mathrm{~m}$ grid. $\mathrm{DBH}$ and height of all trees, including recruits, were measured and mortality recorded after 14 months. The two plots differed in number of stems and basal area (Table 2). The number of species was 21 and 37 in plot 1 and 2, respectively, and 44 in both plots combined. The six most dominant species in both plots were Cecropia peltata, Trichospermum mexicanum, Ochroma pyramidale, Trema micrantha, Trema laxiflora, and Schizolobium parahyba. Together, these species constituted $85 \%$ and $97 \%$ of total basal area in plot 1 and plot 2 , respectively.

\section{Tree selection}

To minimize the dependence between focal tree size and the relative contribution of its smaller neighbors to total neighborhood basal area, we compared performance of focal trees of similar height. Trees were selected from the 3.5-4.5 and 4.5-5.5 m height ranges (henceforth, referred to as the 4- and 5-m height classes, respectively), in which both species were most abundant. For the growth analysis, trees were randomly selected from our database. Trees that were within the neighborhood of a previously selected tree, or that had any kind of visible damage reported in one of the two censuses were discarded. This procedure went on until no new trees could be included. This resulted in four different data sets ( 2 species $\times 2$ height classes) for which all analyses were performed separately with $40-61$ focal trees each.

Table 1 Species characteristics of Cecropia peltata L. (Cp) and Trichospermum mexicanum (DC.) Baill. (Tm)

\begin{tabular}{|c|c|c|c|}
\hline & $\mathrm{Cp}$ & $\mathrm{Tm}$ & Source \\
\hline Dispersal syndrome & Animal & Wind & Burns and Honkala (1990); Fleming and Williams (2009) \\
\hline Mortality (\%) & 69 & 5 & This study; from nine $1-5$ years old study plots over 2 -year period \\
\hline Frequency $(\%)$ & 75 & 62.3 & $\begin{array}{l}\text { Percentage occurrence in } 76 \text { secondary forest plots in the research region } \\
\text { (van Breugel 2007) }\end{array}$ \\
\hline Dominance $(\%)$ & 37.5 & 33.8 & $\begin{array}{l}\text { Percentage of } 76 \text { plots in which the species held } \geq 10 \% \text { of the stand basal area } \\
\text { (van Breugel 2007) }\end{array}$ \\
\hline Maximum life span & 35 & 30 & $\begin{array}{l}\text { Data and observations from long-term studies at Los Tuxtlas and present study region } \\
\text { (M. Martínez-Ramos et al. unpublished data) }\end{array}$ \\
\hline Maximum height & $20(18)$ & $15(18)$ & Pennington and Sarukhán (2005), between parentheses observed maximum in our plots \\
\hline
\end{tabular}


Table 2 Plot characteristics and sample size. Indicated are total number of trees with $\mathrm{DBH} \geq 1 \mathrm{~cm}$ and the sum of their basal areas

\begin{tabular}{llllll}
\hline Height class & \multicolumn{2}{l}{ Number of trees } & & \multicolumn{2}{c}{ Basal Area $\left(\mathrm{m}^{2}\right)$} \\
\cline { 2 - 3 } \cline { 6 - 6 } & Plot 1 & Plot 2 & & Plot 1 & Plot 2 \\
\hline$<3.5 \mathrm{~m}$ & 333 & 790 & 0.08 & 0.11 \\
$3.5-4.5 \mathrm{~m}$ & $176(25 / 31)$ & $418(15 / 30)$ & 0.14 & 0.14 \\
$4.5-5.5 \mathrm{~m}$ & $78(15 / 11)$ & $260(31 / 41)$ & 0.12 & 0.16 \\
$\geq 5.5 \mathrm{~m}$ & 22 & 356 & 0.08 & 0.63 \\
\hline
\end{tabular}

Between brackets the number of selected Cecropia and Trichospermum saplings, respectively

Neighborhood competition

Neighborhood basal area (NBA) was used as a proxy for the level of neighborhood competition. The neighborhood of a focal tree was defined as the area consisting of its own and the 24 adjacent $1 \times 1 \mathrm{~m}$ quadrats. The effect of neighborhood competition on focal tree growth was analyzed with the basal area of neighbors larger than the focal tree $\left(\mathrm{NBA}_{\mathrm{L}}\right)$ and basal area of neighbors smaller than the focal tree $\left(\mathrm{NBA}_{\mathrm{S}}\right)$ as separate predictor variables (correlation coefficients between $\mathrm{NBA}_{\mathrm{L}}$ and $\mathrm{NBA}_{\mathrm{S}}$ varied between $r=0.03$ and $r=0.23, P>0.05$ in all cases). All species were lumped in our measure of NBA, i.e., we tested a model that assumes that all competitors had equivalent effects on the focal tree regardless of their taxonomic identity.

\section{Growth responses}

We used four different variables to quantify the growth response of focal trees: (1) Relative height growth (RHG), calculated as ( $\left.\ln \mathrm{H}_{\text {census } 2}-\ln \mathrm{H}_{\text {census } 1}\right) /(365 / \mathrm{t})$, where $t=$ the study period in days. Plant performance is likely to be correlated with plant size (Duncan 1995), an effect that was accounted for by selecting trees within narrow height classes. (2) The percentage of potential diameter growth rate (PPDG, \%, see next paragraph). Since the potential diameter growth is calculated as a function of size, the size effects on plant performance is accounted for. (3) Slenderness, calculated as the ratio between height and diameter at the initial census $\left(\mathrm{m} \mathrm{cm}^{-1}\right)$. (4) $\Delta$ slenderness, calculated as slenderness ${ }_{\text {census } 2} /$ slenderness $_{\text {census } 1}$.

Potential diameter growth increment (PDG) was estimated by fitting a DBH-growth function (Zeide 1993; Vanclay 1994) through the upper (99\%) quantiles of 2-year growth data using non-linear quantile regression (Scharf et al. 1998; Koenker 2005) (see online resource 1 for more details). Data were from nine 1-5 year old secondary forest plots with similar soil and land-use history. Next, we calculated the annual relative diameter growth rate for each focal tree as (ln $\left.\mathrm{DBH}_{\text {census 2 }}-\ln \mathrm{DBH}_{\text {census 1 }}\right)$ / $(365 / t)$ and multiplied this rate with initial diameter to estimate the annual absolute diameter growth rate (ADG, $\mathrm{cm}^{2}$ year $^{-1}$ ) for each focal tree. PPDG was then calculated as $100 \times \mathrm{ADG} / \mathrm{PDG}(\%)$.

Data analysis

To test the hypothesis of competitive asymmetry, we used multiple linear regression adding the predictor variable $\mathrm{NBA}_{\mathrm{L}}$ first, then $\mathrm{NBA}_{S}$ and finally the interaction term. If $\mathrm{NBA}_{S}$ and the interaction term were significant (type I sum of squares), we checked the type III sum of squares to examine if the effect of $\mathrm{NBA}_{\mathrm{S}}$ on the response variable was additive, an interaction effect, or both. We report statistics of the final models only including the significant factors. To obtain linearity, normality of the residuals and homogeneity of variances, we applied a Box-Cox transformation on the response variables RHG and PPDG (Sokal and Rohlf 1995). No transformation was needed for the other two response variables. Assumptions regarding heteroscedasticity and normality were examined with residual plots and QQ plots (Quinn and Keough 2002).

\section{Results}

Growth and survival

The species had strongly different survival rates. Survival in Cecropia was strongly related to tree size, going up from 18.2 and $28.0 \%$ in the height classes $<3.5$ and $3.5-4.5 \mathrm{~m}$ to 57 and $77.4 \%$ in the $4.5-5.5$ and $>5.5 \mathrm{~m}$ height classes, respectively. Survival in Trichospermum, on the other hand, was very high, with $81.1,93.4,95.7$, and $97.2 \%$ survival, respectively.

Height growth ranged from 0.14 to $4.30 \mathrm{~m} \mathrm{year}^{-1}$ in Cecropia and 0.00-4.60 $\mathrm{m} \mathrm{year}^{-1}$ in Trichospermum. Diameter growth (ADG) of Cecropia ranged from 0.03 to $1.63 \mathrm{~cm} \mathrm{year}^{-1}$ (4-m height class) and $0.03-3.70 \mathrm{~cm} \mathrm{year}^{-1}$ (5-m height class) and from 0.04 
to $5.33 \mathrm{~cm} \mathrm{year}^{-1}$ (4-m height class) and $0.06-5.94 \mathrm{~cm} \mathrm{year}^{-1}$ (5-m height class) for Trichospermum. This is a reduction between 0 and $100 \%$ of potential growth in both species (Fig. 1e-h).

\section{Neighborhood effects}

The neighborhood basal area varied widely among the focal trees, ranging 10 -fold $\left(3-30 \mathrm{~cm}^{2} \mathrm{~m}^{-2}\right.$; Fig. 1) and was dominated by few pioneer species (Online resource 2). The contribution of smaller trees to total NBA area $\left(\mathrm{NBA}_{\mathrm{S}}\right)$ was highly variable and averaged $40.7 \% \pm 25.4$ SD and $50.1 \% \pm 25.4$ SD for the 4and 5-m height class, respectively in Cecropia, and $15.7 \% \pm$ 14.5 SD and $25.2 \% \pm 14.3 \mathrm{SD}$ in Trichospermum. $\mathrm{NBA}_{\mathrm{S}}$ was not significantly correlated with $\mathrm{NBA}_{\mathrm{L}}$ for any species $(P>0.05)$.

The basal area of the larger neighbors $\left(\mathrm{NBA}_{\mathrm{L}}\right)$ had a strong negative effect on the RHG of both Cecropia and Trichospermum in both size classes (Fig. 1a-d; Table 3). $\mathrm{NBA}_{S}$, on the other hand, had no significant additive effect (Table 3), despite its substantial contribution to total NBA. Diameter growth was also strongly negatively related to $\mathrm{NBA}_{\mathrm{L}}$, although with a lower $\mathrm{R}^{2}$ (Fig. 1e-h; Table 3). $\mathrm{NBA}_{\mathrm{S}}$ did have a significant additional effect on diameter growth of Cecropia, but not of Trichospermum (Table 3).

Slenderness at the initial census was linearly and positively related to $\mathrm{NBA}_{\mathrm{L}}$ in all cases (Fig. 2; Table 3). In Trichospermum, $\mathrm{NBA}_{\mathrm{S}}$ did not have a significant additive effect, but the interaction term $\left(\mathrm{NBA}_{\mathrm{L} \times \mathrm{S}}\right)$ was significant and opposite to the effect of $\mathrm{NBA}_{\mathrm{L}}$ (Table 3). During the study period, slenderness increased in nearly all Cecropia trees and the rate of increase was negatively related to $\mathrm{NBA}_{\mathrm{L}}$ (Fig. 2e-f; Table 3). Slenderness of Trichospermum increased in about $50 \%$ of the focal trees, and decrease in the other $50 \%$, but without any relationship with $\mathrm{NBA}_{\mathrm{L}}$ (Fig. $2 \mathrm{~g}-\mathrm{h}$ ). $\mathrm{NBA}_{\mathrm{S}}$, on the other hand, did have a significant positive effect on relative rate of change of slenderness of 4-m high Trichospermum (Table 3).

\section{Discussion}

This study suggests that during early secondary succession aboveground competition for light is more important than belowground competition for nutrients, despite the low soil fertility in this forest. As expected,
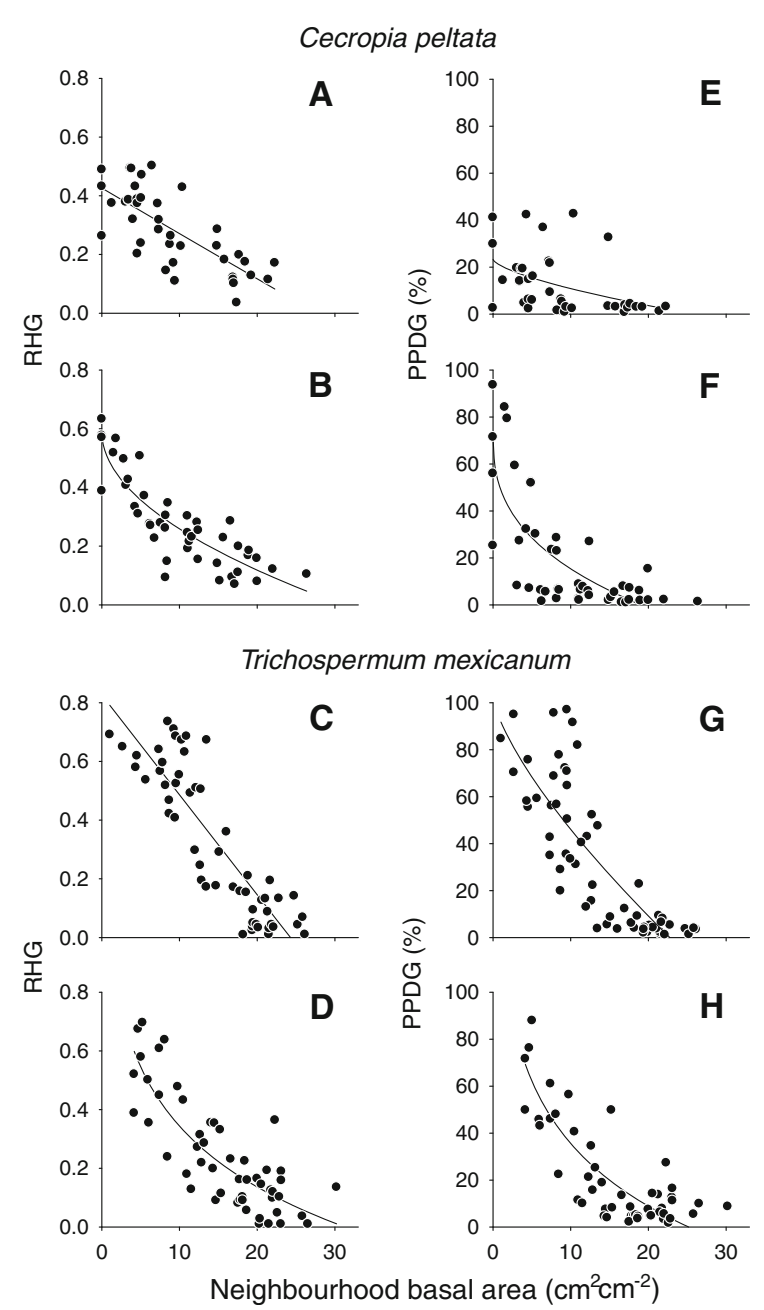

Fig. 1 The relationship between sapling performance and the basal area of larger neighbors. RHG is the relative height growth rate and PPDG is percentage of potential diameter growth rate (\%). Focal species: Cecropia peltata (a, b,e, f), Trichospermum mexicanum (c, d, $\mathbf{g}, \mathbf{h})$. Height class: $3.5-4.5 \mathrm{~m}(\mathbf{a}, \mathbf{c}, \mathbf{e}, \mathbf{g})$; $4.5-5.5 \mathrm{~m}(\mathbf{b}, \mathbf{d}, \mathbf{f}, \mathbf{h})$. Linear $(\mathrm{C})$ and power regression lines are included to illustrate trends $(P \leq 0.01$ in all cases). Test statistics on the relationship between neighborhood competition and sapling growth in Table 3

larger neighbors showed strong effects on growth of focal trees, while smaller neighbors had no or a limited additional competitive effect, suggesting a predominantly asymmetric competition.

Competition from larger neighbors drove variation in growth

Early secondary forests are often described as having a uniform canopy (e.g., Richards et al. 1996). Yet, at the 
Table 3 Relationship of growth with competition for two pioneer species in early successional forest

\begin{tabular}{|c|c|c|c|c|c|c|c|}
\hline \multirow[b]{2}{*}{$\mathrm{HC}$} & \multirow{2}{*}{$\begin{array}{l}\text { RHG } \\
\mathrm{NBA}_{\mathrm{L}}\end{array}$} & \multicolumn{2}{|l|}{ PPDG } & \multicolumn{2}{|c|}{ Slenderness } & \multicolumn{2}{|c|}{$\Delta$ Slenderness } \\
\hline & & $\mathrm{NBA}_{\mathrm{L}}$ & $\mathrm{NBA}_{S}$ & $\mathrm{NBA}_{\mathrm{L}}$ & $\mathrm{NBA}_{\mathrm{LxS}}$ & $\mathrm{NBA}_{\mathrm{L}}$ & $\mathrm{NBA}_{S}$ \\
\hline \multicolumn{8}{|c|}{ Cecropia peltata } \\
\hline $4 \mathrm{~m}$ & $-0.56 * * *$ & $-0.32 * * *$ & $-0.10 * *$ & $+0.70 * * *$ & $n s$ & $-0.46^{* * *}$ & $n s$ \\
\hline $5 \mathrm{~m}$ & $-0.76 * * *$ & $-0.56 * * *$ & $-0.07 * *$ & $+0.73 * * *$ & $n s$ & $-0.16^{* *}$ & $n s$ \\
\hline \multicolumn{8}{|c|}{ Trichospermum mexicanum } \\
\hline $4 \mathrm{~m}$ & $-0.78 * * *$ & $-0.80 * * *$ & $n s$ & $+0.68 * * *$ & $-0.14 * *$ & $n s$ & $+0.20 * *$ \\
\hline $5 \mathrm{~m}$ & $-0.68 * * *$ & $-0.59 * * *$ & $n s$ & $+0.66^{* * *}$ & $-0.05 * *$ & $n s$ & $n s$ \\
\hline
\end{tabular}

Regression statistics of growth variables (response) versus neighborhood basal area (regressor), with RHG = relative height growth; PPDG $=$ percentage of potential absolute diameter growth; Slenderness $=$ height-diameter ratio; $\Delta$ Slenderness $=$ slenderness $_{\text {census }}$ ${ }_{2} /$ slenderness $_{\text {census }} 1$. $\mathrm{HC}$ is height class: $4 \mathrm{~m}=3.5-4.5 \mathrm{~m} ; 5 \mathrm{~m}=4.5-5.5 \mathrm{~m}$. $\mathrm{NBA}_{\mathrm{L}}$ : basal area of larger neighbors, $\mathrm{NBA}_{\mathrm{S}}$ : basal area of smaller neighbors, $\mathrm{NBA}_{\mathrm{Lx} S}$ : interaction term. The table presents the sign of the regression coefficients (i.e., a negative or positive relationship), the partial coefficients of determination (partial $\mathrm{R}^{2}$ ) and the significance level of the regression variables

** $P<0.01, * * * P<0.001, \mathrm{~ns}=P>0.05$

scale of small saplings, neighborhood density varied ten-fold. Along this range of values, and strongly correlated with it, height growth varied over five-fold, and suppression of diameter growth ranged from 0 to $100 \%$. More specifically, most of the variation in diameter and height growth of similar-sized Cecropia and Trichospermum saplings could be explained by the basal area of their larger neighbors, suggesting a predominant role of competition for light.

Smaller neighbors did not have a significant additive effect on height growth, despite representing, on average, $30 \%( \pm 24 \mathrm{SD})$ of the total NBA, nor did they affect diameter growth in Trichospermum. However, smaller neighbors did account for a part of the variation in diameter growth of Cecropia. This may suggest a role of symmetric competition for belowground resources, but we will discuss alternative explanations later.

Competition did not only reduce overall growth rate, but also affected allocation patterns. Initial stem slenderness of both species was strongly related to the basal area of the larger neighbors, reminiscent of the negative relationship between slenderness and light commonly found for light demanding species (King 1994, 1996; Poorter 2001; Sterck 2005; Palomaki et al. 2006). It is not clear why changes in slenderness of Trichospermum saplings during the study period were not related to NBA at all. Slenderness of all Cecropia saplings did increase further but the rate of that increase was negatively related to basal area of larger neighbors. This seems to reflect how, along a temporal gradient of progressively stronger competition for light, trees first limited allocation to diameter growth and then to height growth, thus indicating that the suppressed saplings were getting closer to a negative carbon balance (Bongers and Sterck 1998; Sterck 2005; Turnbull 2005).

Symmetry does not necessarily imply

belowground competition

The significant additive negative effect of the smaller neighbors on diameter growth and survival of Cecropia suggests that competition was at least partially symmetric, which often is taken as an indication that the competition for belowground resources plays an important role (e.g., Thomas and Weiner 1989; Peterson and Squiers 1995). However, it has also been argued that, even if competition is mediated by light, the degree of asymmetry may differ depending on crown allometry of competing trees and canopy structure of the stand (Kikuzawa and Umeki 1996), which may result from species differences (Uriarte et al. 2004, 2005; Selaya et al. 2007; Kuijk et al. 2008; Uriarte et al. 2010).

The latter interpretation is supported by our observation that the basal area of the taller and of the smaller neighbors was not significantly correlated; density patterns of smaller neighbors may thus have reflected variation in local light availability not explained by the neighborhood basal area of larger neighbors (Montgomery and Chazdon 2001). More specifically, $87-95 \%$ of the smaller neighbors belonged to six light-demanding pioneer species (Online Resource 2); 


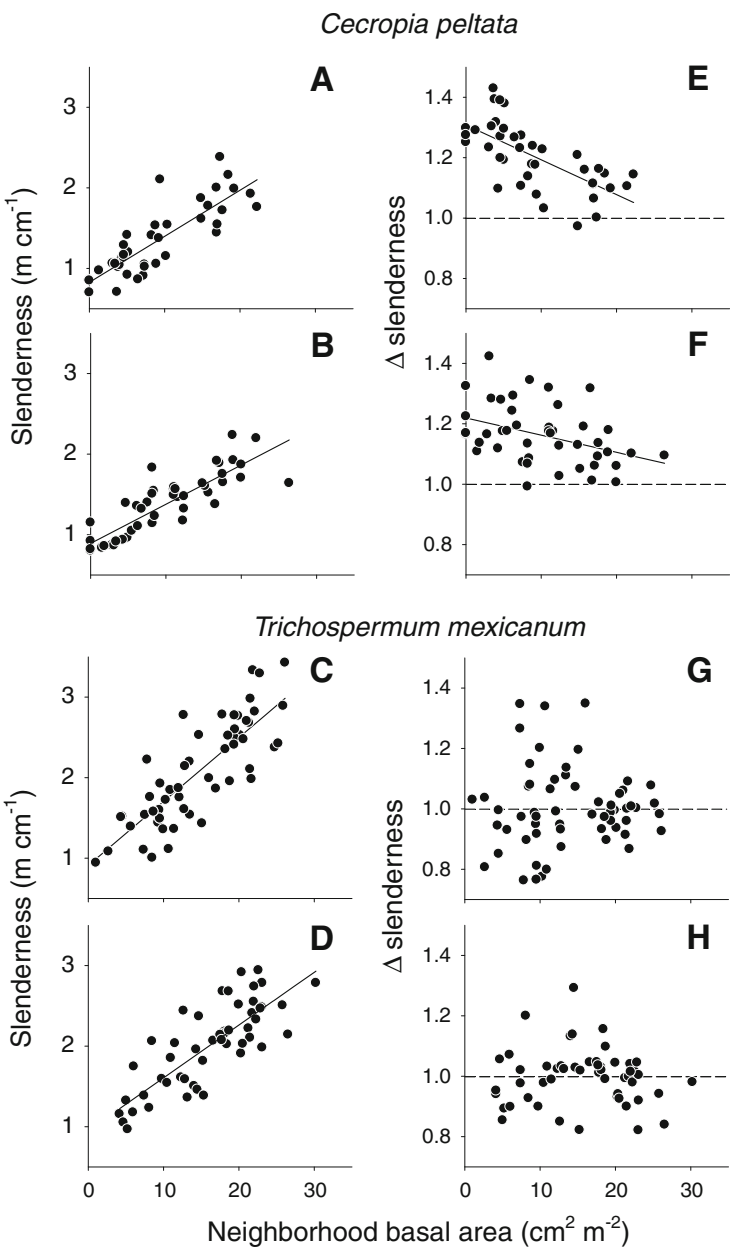

Fig. 2 The effect of neighborhood competition on stem slenderness. Neighborhood is expressed as the basal area of the larger neighbors. Slenderness is calculated as the ratio between height $(\mathrm{m})$ and diameter $(\mathrm{cm})$. Both variables are from first census data. $\Delta$ Slenderness is calculated as the slenderness of the second census divided by the slenderness of the first census, thus slenderness increased above the dashed lines and it decreased below this line. Focal species: Cecropia peltata $(\mathbf{a}, \mathbf{b}$, $\mathbf{e}, \mathbf{f})$, Trichospermum mexicanum (c, d, g, h). Height class: 3.5-4.5 m (a, c, e, g); 4.5-5.5 m (b, d, f, h). Fitted linear regression lines are included to illustrate trends $(P \leq 0.01$ in all cases). Test statistics on the relationship between neighborhood competition and sapling growth in Table 3

high densities of these species likely indicated higher understory light levels. Moreover, an allometry study conducted in our study site found that the relative crown depth of Cecropia, Trichospermum and 10 other of the locally most abundant species (average height $2.7 \mathrm{~m} \pm 0.04 \mathrm{SE}$, van Breugel 2007) was strongly and positively related to light availability.
Combined, these points suggest that a high density of smaller neighbors correlates positively with crown depth, causing competition for light between overlapping crowns of focal trees and their smaller neighbors (Ewel and Mazzarino 2008).

An additional and unrelated indication for a relatively limited role of belowground competition comes from the above mentioned allometry study: Averaged across 260 saplings of 12 species, the projected root area was $3.0( \pm 0.2 \mathrm{SE})$ times smaller than the projected crown area (M. van Breugel unpublished data). Overall, our findings represent strong evidence for a predominant role of light competition during the first years of succession, despite the low soil fertility.

Competition and succession

Cecropia and Trichospermum are the two most widely distributed and abundant species across the secondary forests in our study area (van Breugel 2007). Both are pioneer species with similar maximum age and stature (Table 1) and comparable functional traits (Lohbeck et al. unpublished data), but they differed considerably in growth and survival rates and their tolerance to neighborhood competition. Such differences among dominant species may have a strong effect on community-level species dynamics (Norden et al. 2011); hence understanding their population dynamics is pivotal for a better understanding of secondary forest succession (Gaston and Fuller 2008).

Few studies thus far have directly assessed the role of competition during the early years of tropical forest succession, despite its pre-eminent place in forest succession models. The results of our study strongly suggest a predominant role for light competition as a mechanism shaping population dynamics of tree species during the initial phase of secondary forest succession. They also show that competition may start and strongly intensify within the first 1-2 years of succession and can drive most of the variation in growth and survival among saplings of early successional species (stem exclusion phase, cf. Finegan 1996; Chazdon 2008).

Competition during the first years of succession was found to be largely asymmetric in a fallow in its first slash-and-burn cycle in the Bolivian Amazon (Selaya 2007), but was found to be largely symmetric in a fallow in Vietnam on a soil that was very degraded after multiple cycles of plantation use (Kuijk et al. 
2008). Overall growth in the Vietnam site was much slower than in our site and the Bolivian site (van Breugel et al. 2006; Kuijk et al. 2008; Selaya et al. 2008). The intensity and the degree of size-asymmetry in competition may thus, as hypothesized by Schwinning and Weiner (1998) and Wilson (1999), change along a gradient of site productivity. To elucidate the generality and variation of specific processes, such as competition along gradients of soil fertility, land-use or precipitation, we will need comparative analyses that include many more local studies (Keddy 2001). An increasing number of longitudinal studies in secondary tropical forests (Chazdon et al. 2007; van Breugel et al. 2006, 2007; Brienen et al. 2009; LebrijaTrejos et al. 2010; Maza-Villalobos et al. 2011; Norden et al. 2011) hold the promise that such comparative analyses will soon be possible, and that the generality of changes in the importance of aboveversus belowground competition along such gradients will be determined.

Acknowledgments We thank Gilberto and Hector Jamangapee for help with data collection, Marco Dekker and two anonymous reviewers for comments. This research was supported by Grant W85-326 of the Netherlands Foundation for the Advancement of Tropical Research (WOTRO-NWO) to FB and MvB and Grant SEMARNAT-CONACyT 2002-C01-0597 to MMR. MvB acknowledges financial support by the HSBC Climate Partnership, PAJ support from the Netherlands Foundation for Scientific Research (NWO-ALW) and MMR a sabbatical fellowship from DAGAP-UNAM and CONACYT.

Open Access This article is distributed under the terms of the Creative Commons Attribution Noncommercial License which permits any noncommercial use, distribution, and reproduction in any medium, provided the original author(s) and source are credited.

\section{References}

Bazzaz FA (1990) Plant-plant interactions in successional environments. In: Grace JB, Tilman D (eds) Perspectives on plant competition. Academic Press, San Diego USA, pp 239-263

Bazzaz FA (1996) Plants in changing environments: linking physiological, population, and community ecology. Cambridge University Press, Cambridge

Belcher JES, Keddy PA, Twolan-Strutt L (1995) Root and shoot competition intensity along a soil depth gradient. J Ecol 83:673-682

Berntson GM, Wayne PM (2000) Characterizing the size dependence of resource acquisition within crowded plant populations. Ecology 81:1072-1085
Bongers F, Sterck FJ (1998) Architecture and development of rainforest trees: responses to light variation. In: Newberry DM, Prins HHT (eds) Dynamics of tropical communities. Chapman and Hall, London, pp 125-162

Brienen RJW, Lebrija-Trejos E, van Breugel M, Pérez-García EA, Bongers F, Meave JA, Martínez-Ramos M (2009) The potential of tree rings for the study of forest succession in southern Mexico. Biotropica 41:186-195

Burns RM, Honkala BH (1990) Silvics of north America. U.S. Department of Agriculture, Forest Service, Washington

Casper BB, Schenk HJ, Jackson RRB (2003) Defining a plant's belowground zone of influence. Ecology 84: 2313-2321

Chazdon RL (2008) Chance and determinism in tropical forest succession. In: Carson WP, Schnitzer SA (eds) Tropical forest community ecology. Wiley-Blackwell, West Sussex, pp 384-408

Chazdon RL, Letcher SG, van Breugel M, Martínez-Ramos M, Bongers F, Finegan B (2007) Rates of change in tree communities of secondary neotropical forests following major disturbances. Philos Trans R Soc B Biol Sci 362:273-289

Chazdon RL, Peres CA, Dent D, Sheil D, Lugo AE, Lamb D, Stork NE, Miller SE (2009) The potential for species conservation in tropical secondary forests. Conserv Biol 23:1406-1417

de Jong BHJ, Ochoa-Gaona S, Castillo-Santiago MA, RamírezMarcial N, Cairns MA (2000) Carbon flux and patterns of land-use/land-cover change in the Selva Lacandona, Mexico. Ambio 29:504-511

Dent DH, Wright JS (2009) The future of tropical species in secondary forests: a quantitative review. Biol Conserv 142:2833-2843

Duncan RP (1995) A correction for including competitive asymmetry in measures of local interference in plant populations. Oecologia 103:393-396

Ewel JJ, Mazzarino MJ (2008) Competition from below for light and nutrients shifts productivity among tropical species. Proc Natl Acad Sci 105:18836-18841

Feldpausch TR, Riha SJ, Fernandes ECM, Wandelli EV (2005) Development of forest structure and leaf area in secondary forests regenerating on abandoned pastures in central Amazônia. Earth Interact 9:1-22

Finegan B (1996) Pattern and process in neotropical secondary rain forests: the first 100 years of succession. Trends Ecol Evol 11:119-124

Fleming TH, Williams CF (2009) Phenology, seed dispersal, and recruitment in Cecropia peltata (Moraceae) in Costa Rican tropical dry forest. J Trop Ecol 6:163

Fonseca W, Rey Benayas JM, Alice FE (2011) Carbon accumulation in the biomass and soil of different aged secondary forests in the humid tropics of Costa Rica. For Ecol Manag 262:1400-1408

Gardner TA, Barlow J, Chazdon R, Ewers RM, Harvey CA, Peres CA, Sodhi NS (2009) Prospects for tropical forest biodiversity in a human-modified world. Ecol Lett 12:561-582

Gaston KJ, Fuller RA (2008) Commonness, population depletion and conservation biology. Trends Ecol Evol 23:14-19

Grime JP (2002) Plant strategies, vegetation processes, and ecosystem properties. Wiley, West Sussex 
Hansen MC, DeFries RS (2004) Detecting long-term global forest change using continuous fields of tree-cover maps from $8-\mathrm{km}$ advanced very high resolution radiometer (AVHRR) data for the years 1982-99. Ecosystems 7:695-716

Huston MA, Smith T (1987) Plant succession: life history and competition. Am Nat 130:168-198

Ibarra-Manríquez G, Martínez-Ramos M (2002) Landscape variation of liana communities in a neotropical rain forest. Plant Ecol 160:91-112

Keddy PA (2001) In: MB Usher (ed) Competition. Kluwer Academic Publishers, Dordrecht

Kikuzawa K, Umeki K (1996) Effect of canopy structure on degree of asymmetry of competition in two forest stands in Northern Japan. Ann Bot 77:565-571

King DA (1994) Influence of light level on the growth and morphology of saplings in a Panamanian forest. Am J Bot 81:948-957

King DA (1996) Allometry and life history of tropical trees. J Trop Ecol 12:25-44

Koenker R (2005) Quantile regression. Cambridge University Press, Cambridge

Kohyama T, Hotta M (1990) Significance of allometry in tropical saplings. Funct Ecol 4:515-522

Kuijk M, Anten NPR, Oomen RJ, Bentum DW, Werger MJA (2008) The limited importance of size-asymmetric light competition and growth of pioneer species in early secondary forest succession in Vietnam. Oecologia 157:1-12

Lebrija-Trejos E, Meave JA, Poorter L, Pérez-García EA, Bongers F (2010) Pathways, mechanisms and predictability of vegetation change during tropical dry forest succession. Perspectives in Plant Ecology, Evolution and Systematics 12:267-275

Maza-Villalobos S, Balvanera P, Martínez-Ramos M (2011) Early regeneration of tropical dry forest from abandoned pastures: contrasting chronosequence and dynamic approaches. Biotropica 43(6):666-675. doi:10.1111/j.1744-7429. 2011.00755

Montgomery RA, Chazdon RL (2001) Forest structure, canopy architecture, and light transmittance in tropical wet forests. Ecology 82:2707-2718

Noordwijk Mv, Lawson G, Soumaré A, Groot JJR, Hairiah K (1996) Root distribution of trees and crops: competition and/or complementarity. In: Ong CK, Huxley P (eds) Treecrop interactions. $\mathrm{CAB}$ International, Wallingford, pp 319-364

Norden N, Mesquita RCG, Bentos TV, Chazdon RL, Williamson GB (2011) Contrasting community compensatory trends in alternative successional pathways in central Amazonia. Oikos 120:143-151

Palomaki MB, Chazdon RL, Arroyo JP, Letcher SG (2006) Juvenile tree growth in relation to light availability in second-growth tropical rain forests. J Trop Ecol 22: 223-226

Peet RK, Christensen NL (1980) Succession: a population process. Plant Ecol 43:131-140

Pennington TD, Sarukhán J (2005) Árboles tropicales de México. Manual para la identificación de las principales especies. Universidad Nacional Autónoma de México, Fondo de cultura Económica, México
Peterson C, Squiers E (1995) Competition and succession in an aspen-white-pine forest. J Ecol 83:449-457

Poorter L (2001) Light-dependent changes in biomass allocation and their importance for growth of rain forest tree species. Funct Ecol 15:113-123

Potvin C, Dutilleul P (2009) Neighborhood effects and sizeasymmetric competition in a tree plantation varying in diversity. Ecology 90:321-327

Quinn GP, Keough MJ (2002) Experimental design and data analysis for biologists. Cambridge University Press, Cambridge

Rajaniemi T (2003) Evidence for size asymmetry of belowground competition. Basic Appl Ecol 4:239-247

Richards PW, Walsh RPD, Baillie IC, Greig-Smith P (1996) The tropical rain forest: an ecological study. Cambridge University Press, Cambridge

Saldarriaga JG, Luxmoore RJ (1991) Solar energy conversion efficiencies during succession of a tropical rain forest in Amazonia. J Trop Ecol 7:233-242

Scharf FS, Juanes F, Sutherland M (1998) Inferring ecological relationships from the edges of scatter diagrams: comparison of regression techniques. Ecology 79:448-460

Schwinning S, Weiner J (1998) Mechanisms determining the degree of size asymmetry in competition among plants. Oecologia 113:447-455

Selaya NG (2007) Sprinting, climbing and persisting: light interception and carbon gain in a secondary tropical forest succession. PhD dissertation, Utrecht University, Utrecht, The Netherlands/PROMAB Scientific Series 11

Selaya NG, Anten NPR, Oomen RJ, Matthies M, Werger MJA (2007) Above-ground biomass investments and light interception of tropical forest trees and lianas early in succession. Ann Bot 99:141-151

Selaya NG, Oomen RJ, Netten JJC, Werger MJA, Anten NPR (2008) Biomass allocation and leaf life span in relation to light interception by tropical forest plants during the first years of secondary succession. J Ecol 96:1211-1221

Sokal RR, Rohlf FJ (1995) Biometry, The principles and practice of statistics in biological research. WH Freeman, New York

Sterck FJ (2005) Woody tree architecture. In: Turnbull CGN (ed) Plant architecture and its manipulation. Annual Plant Reviews. Blackwell Publishing Ltd, Oxford, pp 210-237

Swaine MD, Hall JB (1983) Early succession on cleared forest land in Ghana. J Ecol 71:601-628

Thomas SC, Weiner J (1989) Including competitive asymmetry in measures of local interference in plant populations. Oecologia 80:349-355

Turnbull CGN (2005) Shoot architecture II control of branching. In: Turnbull CGN (ed) Plant architecture and its manipulation. Annual Plant Reviews. Blackwell Publishing Ltd, Oxford, pp 92-120

Uhl C (1987) Factors controlling succession following slashand-burn agriculture in Amazonia. J Ecol 75:377-408

Uriarte M, Condit R, Canham CD, Hubbell SP (2004) A spatially explicit model of sapling growth in a tropical forest: does the identity of neighbours matter? J Ecol 92:348-360

Uriarte M, Hubbell SP, Condit R, Canham CD (2005) Neighborhood effects on sapling growth and survival in a neotropical forest and the ecological equivalence hypothesis. 
In: Burslem D (ed) Biological interactions in the tropics. Blackwell Publishing, Oxford, pp 89-106

Uriarte M, Swenson NG, Chazdon RL, Comita LS, kress WJ, Erickson D, Forero-Montana J, Zimmerman JK, Thompson J (2010) Trait similarity, shared ancestry and the structure of neighbourhood interactions in a subtropical wet forest: implications for community assembly. Ecol Lett 13:15031514

van Breugel M (2007) Dynamics of secondary forests. PhD dissertation. C.T. de Wit graduate school production ecology \& resource conservation, Wageningen University, Wageningen, The Netherlands

van Breugel M, Martínez-Ramos M, Bongers F (2006) Community dynamics during early secondary succession in Mexican tropical rain forests. J Trop Ecol 22:663-674

van Breugel M, Bongers F, Martínez-Ramos M (2007) Species dynamics during early secondary forest succession: recruitment, mortality and species turnover. Biotropica 39:610-619
Vanclay JK (1994) Modelling forest growth and yield. Applications to mixed tropical forests. CAB International, Wallingford

Weiner J (1990) Asymmetric competition in plant populations. Trends Ecol Evol 5:360-364

Wilson SD (1999) Plant interactions during secondary succession. In: Walker Lawrence R (ed) Ecosystems of disturbed ground. Ecosystems of the world. Elsevier, Amsterdam, pp 611-632

Zeide B (1993) Analysis of growth equations. Forest Sci 39:594-616

Zermeño Hernández IE (2008) Evaluación del disturbio ecológico provocado por diferentes tipos de uso agrícola del suelo en una región tropical húmedo. MSc. Thesis, Universidad Nacional Autónoma de México, Morelia, Michoacán, México 